\title{
Antinociceptive and Anti-Inflammatory Activities of Satureja hortensis Seed Essential Oil, Hydroalcoholic and Polyphenolic Extracts in Animal Models
}

\author{
Valiollah Hajhashemi ${ }^{a}$ Behzad Zolfaghari ${ }^{b}$ Abbas Yousefi ${ }^{a}$ \\ a Department of Pharmacology and Isfahan Pharmaceutical Sciences Research Center, School of Pharmacy and \\ Pharmaceutical Sciences, Isfahan University of Medical Sciences, and ${ }^{b}$ Department of Pharmacognosy, School of \\ Pharmacy and Pharmaceutical Sciences, Isfahan University of Medical Sciences, Isfahan, Iran
}

\section{Key Words}

Acetic acid test · Analgesic $\cdot$ Formalin test $\cdot$ Lamiaceae $\cdot$ Paw edema $\cdot$ Satureja hortensis

\begin{abstract}
Objective: The aim of this study was to evaluate the antiinflammatory and analgesic effects of Satureja hortensis seed extracts and to analyze their essential oil constituents. Materials and Methods: Hydroalcoholic and polyphenolic extracts and essential oil of S. hortensis seeds were prepared using standard methods. Analgesic activity was assessed in male mice (25-35 g) using standard methods (acetic acid and formalin tests). For the evaluation of anti-inflammatory activity, the carrageenan-induced rat paw edema test was used. The mice were pretreated with 50, 100 or $200 \mathrm{mg} / \mathrm{kg}$, i.p., hydroalcoholic or polyphenolic extracts or 100 or $200 \mu \mathrm{l} /$ kg, p.o. Results: Hydrodistillation of the seeds of S. hortensis afforded a pale yellowish oil in a yield of $0.05 \%(\mathrm{v} / \mathrm{w})$. Pretreatment of mice with hydroalcoholic or polyphenolic extracts or essential oil significantly $(p<0.001)$ reduced acetic acid-induced abdominal twitches. Hydroalcoholic extracts also significantly reduced pain responses in early and late phases of the formalin test whereas the polyphenolic extract and essential oil were only effective in the late phase of the formalin test. All three fractions were found to reduce paw
\end{abstract}

edema in the carrageenan test. Conclusion: These results clearly demonstrate the analgesic and anti-inflammatory activity of S. hortensis seeds and since the hydroalcoholic extract relieved pain in the first phase of the formalin test, it seems that at least part of its analgesic activity may be mediated centrally. The results of this study substantiated the traditional use of $S$. hortensis plant seeds in painful and inflammatory ailments.

Copyright $\odot 2011$ S. Karger AG, Basel

\section{Introduction}

Over the past several years, a number of medicinal plants have been investigated for their possible anti-inflammatory and antinociceptive activities [1-6]. One of them is Satureja hortensis L. (summer savory) [2] which belongs to the Lamiaceae family and is a well-known medicinal herb in Iran. Aerial parts of this plant are frequently used as a food additive and also as a traditional remedy to treat various disorders including cramps, muscle pain, nausea, indigestion, diarrhea and infectious diseases, based on the antispasmodic, antidiarrheal, antibacterial and antifungal properties of their constituents [2, 7-10]. Antioxidant activity has also been reported for aerial parts of the plant $[7,11]$. Previously, we reported

\section{KARGER}

Fax +41613061234 E-Mail karger@karger.ch www.karger.com

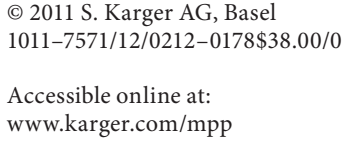

Valiollah Hajhashemi

Department of Pharmacology

School of Pharmacy and Pharmaceutical Sciences

Isfahan University of Medical Sciences, Isfahan (Iran)

Tel. +98 311792 2630, E-Mail vhajhashemi@gmail.com 
analgesic and anti-inflammatory activities for extracts and essential oil of aerial parts of $S$. hortensis [2]. Since some of the active principles are accumulated in high concentration in the seeds and based on traditional uses of S. hortensis seeds in painful conditions including rheumatism [12], this study aimed to investigate the possible pharmacological basis of these claims. We also characterized seed essential oil constituents by gaschromatography/mass spectrometry (GC/MS) analysis.

\section{Materials and Methods}

Plant Material and Preparation of Extracts and Essential Oil

Seeds of S. hortensis were collected from Isfahan, Iran, in September 2008 and confirmed by the Herbarium Department of the Iranian Research Institute of Forests and Rangelands, Isfahan. A reference specimen of the plant was deposited at the Department of Pharmacognosy, Isfahan University of Medical Sciences.

Essential Oil Preparation. Seeds were pulverized into a powder $(1,500 \mathrm{~g})$ which was then hydrodistilled in a Clevenger-type apparatus for $4 \mathrm{~h}$, and the essential oil obtained was stored in a sealed vial at $4^{\circ} \mathrm{C}$ prior to analysis and experimentation.

Hydroalcoholic Extract Preparation. Powdered seeds were macerated in EtOH: $\mathrm{H}_{2} \mathrm{O}$ (7:3) for 2 days. The extract was then shaken, filtered and freeze-dried. The yield (percent of extract weight to initial weight of seed powder) was 9.5\% [13].

Polyphenolic Fraction Preparation. Powdered seeds were first extracted with EtOH: $\mathrm{H}_{2} \mathrm{O}(9: 1)$ and filtered. The residue was then extracted with EtOH: $\mathrm{H}_{2} \mathrm{O}$ (1:1). The combined extracts were evaporated to about one third of their original volume and finally extracted with chloroform in a separatory funnel. The resulting aqueous solution was freeze-dried and its yield (percent of extract weight to initial weight of seed powder) was $4.5 \%$ [13].

\section{GC/MS Analysis and Characterization of the Components of}

the Essential Oils

GC/MS (Hewlett-Packard, USA) was used for the identification of essential oil components. The analysis was performed using a Hewlett-Packard 5792A mass selective detector coupled with a Hewlett-Packard 6890 GC, equipped with an HP-5MS capillary column $(30 \mathrm{~m} \times 0.25 \mathrm{~mm}$; film thickness $0.25 \mu \mathrm{m})$. The oven temperature was programmed from $60-280^{\circ} \mathrm{C}$ at $4^{\circ} \mathrm{C} / \mathrm{min}$. Helium was used as carrier gas at a flow rate of $2 \mathrm{ml} / \mathrm{min}$. Injector and detector temperatures were $280^{\circ} \mathrm{C}$. The MS operating parameters were as follows: ionization voltage, $70 \mathrm{eV}$; ion source temperature, $250^{\circ} \mathrm{C}$; ionization current $750 \mu \mathrm{A}$.

The identification of the oil constituents was based on computer matching against library spectra (Library Database Wiley $275 \mathrm{~L}$ ), their retention indices with reference to an n-alkane series in a temperature-programmed run, interpretation of their fragmentation pattern and comparison of the mass spectra with those reported in the literature $[14,15]$.

\section{Animals}

Pain tests were carried out on male Swiss mice (25-35 g). Male Wistar rats (160-200 g) were used for the carrageenan test. The animals were housed in groups of 6 per standard cage, on a 12hour light/dark cycle, and air temperature was maintained at 22 $\pm 2{ }^{\circ} \mathrm{C}$ with access to food and water ad libitum. They were acclimatized to laboratory conditions for at least 1 week before testing. Each experimental group consisted of 8 animals. All experiments were performed according to guidelines for the care of laboratory animals of Ethics Committee of Isfahan University of Medical Sciences.

\section{Acetic Acid-Induced Writhing Test}

This test, which is used to assess analgesic activity, was carried out according to the method described by Koster et al. [16]. Groups of mice $(n=8)$ were intraperitonally administered various doses $(50-200 \mathrm{mg} / \mathrm{kg}$ ) of hydroalcoholic or polyphenolic extract $30 \mathrm{~min}$ prior to an intraperitoneal injection of $1 \%$ acetic acid in a volume of $10 \mathrm{ml} / \mathrm{kg}$. Essential oil was given orally by gavage $45 \mathrm{~min}$ before acetic acid injection. The control group received vehicle $(10 \mathrm{ml} / \mathrm{kg}$ of $1 \%$ solution of Tween 80$)$. Indomethacin $(10 \mathrm{mg} / \mathrm{kg}$, i.p.) was used as a reference analgesic and anti-inflammatory drug. Tween 80 was used to make a uniform suspension of the extracts or indomethacin and to emulsify the essential oil.

\section{Formalin Test}

This test, which is used to assess analgesic activity, was carried out on male Swiss mice $(n=8)$ according to the method described by Hunskaar and Hole [17]. Briefly, $30 \mathrm{~min}$ after the intraperitoneal injection of vehicle, reference drug (morphine, $10 \mathrm{mg} / \mathrm{kg}$ ), the above-mentioned doses of the hydroalcoholic or polyphenolic extracts or $45 \mathrm{~min}$ following the oral administration of various doses of the essential oil, $20 \mathrm{dl}$ of $2.5 \%$ formalin (v/v in $0.9 \% \mathrm{sa}-$ line) was injected into the subplantar space of the right hind paw and the duration of paw licking was determined $0-5$ min (first phase) and 20-30 min (second phase) following the injection of formalin.

\section{Carrageenan-Induced Rat Paw Edema}

Anti-inflammatory activity was evaluated in male Wistar rats using the carrageenan-induced paw edema test [18]. The animals were lightly anesthetized with ether, and acute inflammation was then induced by a subplantar injection (into the right hind paw) of $0.1 \mathrm{ml}$ of a freshly prepared suspension of carrageenan $(1 \% \mathrm{w} / \mathrm{v})$ in isotonic saline. The left hind paw was injected with $0.1 \mathrm{ml} \mathrm{sa-}$ line and used as control. Paw volume was measured prior to and $4 \mathrm{~h}$ after carrageenan administration using a mercury plethysmorgraph (Ugo Basil, Italy).

Hydroalcoholic and polyphenolic extracts were injected intraperitoneally $30 \mathrm{~min}$ prior to the administration of the carrageenan. Essential oil was uniformly dispersed in saline containing Tween $80(1 \% \mathrm{v} / \mathrm{v})$ and administered by gavage $1 \mathrm{~h}$ prior to carrageenan injection. The control group received an equal volume of the vehicle. Indomethacin $(10 \mathrm{mg} / \mathrm{kg}$, i.p.) was used as positive analgesic control.

\section{Statistical Analysis}

Data were analyzed by SPSS (version 13) using one-way analysis of variance followed by the Duncan test. The results are expressed as mean \pm SEM and differences were considered significant at a level of $\mathrm{p}<0.05$. 


\section{Results}

\section{Analysis of the Essential Oil}

The yield of $S$. hortensis seed essential oil was $0.05 \%$ $(\mathrm{v} / \mathrm{w})$ and 10 compounds, comprising $98.7 \%$ of the seed oil were identified (table 1): $\gamma$-terpinen (50.5\%) and thymol (32.7\%) were the two main constituents of the seed oil.

\section{Pharmacological Study}

In the acetic acid-induced writhing test, $S$. hortensis seed hydroalcoholic extract and polyphenolic extract at doses of 50, 100 and $200 \mathrm{mg} / \mathrm{kg}$ and $S$. hortensis essential oil, at doses of 100 and $200 \mu \mathrm{l} / \mathrm{kg}$, significantly $(\mathrm{p}<0.001)$ inhibited abdominal writhes. Indomethacin, a standard drug with analgesic and anti-inflammatory activity at a dose of $10 \mathrm{mg} / \mathrm{kg}$, produced a $90 \%$ reduction of writhes (table 2).

In the acute phase of the formalin test (table 3), only the hydroalcoholic extract (50, 100 and $200 \mathrm{mg} / \mathrm{kg})$ significantly $(\mathrm{p}<0.01)$ reduced paw licking time and this effect was not dose dependent at the doses tested. In the chronic phase of the formalin test, both extracts (hydroalcoholic extract and polyphenolic extract) and also the essential oil significantly inhibited formalin-induced licking behavior. Morphine, a standard analgesic drug, also produced a significant $(\mathrm{p}<0.001)$ reduction in paw licking time in both phases of the formalin test.

In carrageenan-induced paw edema, hydroalcoholic extract (100 and $200 \mathrm{mg} / \mathrm{kg}$ ), polyphenolic extract (400 $\mathrm{mg} / \mathrm{kg}$ ) and essential oil ( $(400 \mu \mathrm{l} / \mathrm{kg})$ all significantly $(\mathrm{p}<$ 0.05 ) reduced inflammation (table 4 ). As expected, indomethacin $(10 \mathrm{mg} / \mathrm{kg}$, i.p.) also produced significant $(\mathrm{p}<$ 0.001 ) inhibition of carrageenan-induced paw edema.

\section{Discussion}

\section{Pharmacognosy}

Analysis of the essential oil derived from S. hortensis seeds showed some diversity in the constituents due to biodiversity and ecological factors. Our sample contained $\gamma$-terpinen and thymol as major components whereas carvacrol (60\%) and $\gamma$-terpinen (13\%) were found to be the main constituents of essential oil of $S$. hortensis seeds in a previous study [19]. It has been reported that the composition of any plant essential oil is influenced by several factors including local, climatic, seasonal, harvesting, storage and experimental conditions [20], and these factors may explain the differences between our results and the previous work.
Table 1. Percentage composition of the seed oil of the Iranian S. hortensis

\begin{tabular}{rrllc}
\hline Number & $\begin{array}{l}\text { Retention } \\
\text { time }\end{array}$ & Compound & $\begin{array}{l}\text { Percent } \\
\text { (from TIC } \\
\text { data) }\end{array}$ & $\begin{array}{l}\text { Retention } \\
\text { indices }\end{array}$ \\
\hline 1 & 3.41 & $\alpha$-thujen & 0.89 & 930 \\
2 & 3.54 & $\alpha$-pinene & 0.80 & 938 \\
3 & 4.31 & $\beta$-pinene & 0.36 & 982 \\
4 & 4.59 & myrcene & 0.91 & 993 \\
5 & 5.17 & $\alpha$-terpinen & 2.86 & 1,021 \\
6 & 5.41 & $\rho$-cymene & 9.18 & 1,033 \\
7 & 6.45 & $\gamma$-terpinene & 50.45 & 1,074 \\
8 & 13.86 & thymol & 32.67 & 1,321 \\
9 & 15.52 & carvacrol acetate & 0.24 & 1,377 \\
10 & 16.77 & $\beta$-caryophyllene & 0.34 & 1,417 \\
\hline
\end{tabular}

${ }^{1}$ The retention indices are the retention time normalised to the retention times of adjacently eluting n-alkanes.

Table 2. Effect of extracts and essential oil of S. hortensis seeds on acetic acid-induced writhing in mice $(n=8)$

\begin{tabular}{lccc}
\hline Treatment & Dose & $\begin{array}{l}\text { Writhes, } \\
\text { mean } \pm \text { SEM }\end{array}$ & $\begin{array}{l}\text { Inhibition, } \\
\%\end{array}$ \\
\hline Control & - & $67.6 \pm 3.0$ & - \\
$\mathrm{HE}$ & $50 \mathrm{mg} / \mathrm{kg}$ (i.p.) & $17.2 \pm 3.1^{*}$ & 75 \\
& $100 \mathrm{mg} / \mathrm{kg}$ (i.p.) & $2.2 \pm 0.7^{*}$ & 96 \\
$\mathrm{PE}$ & $200 \mathrm{mg} / \mathrm{kg}$ (i.p.) & $1.8 \pm 0.9^{*}$ & 97 \\
& $50 \mathrm{mg} / \mathrm{kg}$ (i.p.) & $35.5 \pm 3.0^{*}$ & 47 \\
& $100 \mathrm{mg} / \mathrm{kg}$ (i.p.) & $15.5 \pm 2.2^{*}$ & 77 \\
EO & $200 \mathrm{mg} / \mathrm{kg}$ (i.p.) & $8.8 \pm 1.3^{*}$ & 87 \\
& $100 \mu \mathrm{l} / \mathrm{kg}$ (p.o.) & $44.0 \pm 3.6^{*}$ & 35 \\
Indomethacin & $100 \mathrm{mg} / \mathrm{kg}$ (p.o.) & $22.2 \pm 0.9^{*}$ & 67 \\
& & $7.0 \pm 2.6^{*}$ & 90 \\
\hline
\end{tabular}

* $\mathrm{p}<0.001$ compared with control group. HE $=$ Hydroalcoholic extract; $\mathrm{PE}=$ polyphenolic extract; $\mathrm{EO}=$ essential oil.

\section{Pharmacology}

In the present study, $S$. hortensis extracts and seed essential oil showed analgesic activity in acetic acid-induced writhing and formalin tests. Acetic acid-induced abdominal pain is not a specific model, but because of its similarity to the signs of human visceral disorders it has been extensively used for the screening of analgesic drugs $[21,22]$. In this test, many drugs including opioids, nonsteroidal anti-inflammatory drugs, antispasmodics, calcium channel blockers and antihistamines, show analgesic activity $[22,23]$. 
Table 3. Effect of extracts and essential oil of S. hortensis seeds in the formalin test $(\mathrm{n}=8)$

\begin{tabular}{|c|c|c|c|c|c|}
\hline Group & Dose & $\begin{array}{l}\text { Paw licking time, } \\
\text { first phase } \\
(0-5 \text { min }), s \text {, } \\
\text { mean } \pm \text { SEM }\end{array}$ & $\begin{array}{l}\text { Inhibition, } \\
\%\end{array}$ & $\begin{array}{l}\text { Paw licking time, } \\
\text { second phase } \\
(20-30 \text { min }), s \\
\text { means } \pm \text { SEMs }\end{array}$ & $\begin{array}{l}\text { Inhibition, } \\
\%\end{array}$ \\
\hline Control & - & $99.3 \pm 3.6$ & - & $120.3 \pm 7.9$ & - \\
\hline \multirow[t]{3}{*}{$\mathrm{HE}$} & 50 mg/kg (i.p.) & $67.5 \pm 3.6^{* *}$ & 32 & $65.7 \pm 10.6^{* * *}$ & 45 \\
\hline & 100 mg/kg (i.p.) & $65.0 \pm 4.9^{* *}$ & 35 & $4.7 \pm 1.2^{* * *}$ & 96 \\
\hline & 200 mg/kg (i.p.) & $61.5 \pm 11.8^{* *}$ & 38 & $3.3 \pm 0.9^{* * *}$ & 97 \\
\hline \multirow[t]{3}{*}{$\mathrm{PE}$} & 50 mg/kg (i.p.) & $100.7 \pm 6.7$ & -1 & $91.8 \pm 7.2^{*}$ & 24 \\
\hline & 100 mg/kg (i.p.) & $96.0 \pm 9.1$ & 3 & $89.0 \pm 3.7^{*}$ & 26 \\
\hline & 200 mg/kg (i.p.) & $95.2 \pm 6.5$ & 4 & $50.1 \pm 6.4^{* * *}$ & 58 \\
\hline \multirow[t]{2}{*}{ EO } & $200 \mu \mathrm{l} / \mathrm{kg}$ (p.o.) & $86.0 \pm 6.2$ & 13 & $83.5 \pm 6.0^{*}$ & 31 \\
\hline & $400 \mu \mathrm{l} / \mathrm{kg}$ (p.o.) & $73.8 \pm 6.0$ & 26 & $79.6 \pm 8.6^{*}$ & 34 \\
\hline Morphine & 10 mg/kg (i.p.) & $4.1 \pm 1.5^{* * *}$ & 96 & $3.5 \pm 1.7^{* * *}$ & 97 \\
\hline
\end{tabular}

${ }^{*} \mathrm{p}<0.05,{ }^{* *} \mathrm{p}<0.01,{ }^{* * *} \mathrm{p}<0.001$, compared with control group. HE $=$ Hydroalcoholic extract; $\mathrm{PE}=$ polyphenolic extract; $\mathrm{EO}=$ essential oil.

Table 4. Effect of extracts and essential oil of $S$. hortensis seeds on carrageenan-induced rat paw edema $(\mathrm{n}=8)$

\begin{tabular}{lcll}
\hline Treatment & Dose & $\begin{array}{l}\text { Increase in paw } \\
\text { volume, ml }\end{array}$ & $\begin{array}{l}\text { Inhibition } \\
\text { of paw } \\
\text { edema, \% }\end{array}$ \\
\hline Control & - & $0.36 \pm 0.03$ & - \\
$\mathrm{HE}$ & $50 \mathrm{mg} / \mathrm{kg}$ (i.p.) & $0.29 \pm 0.02$ & 19 \\
& $100 \mathrm{mg} / \mathrm{kg}$ (i.p.) & $0.21 \pm 0.04^{*}$ & 42 \\
$\mathrm{PE}$ & $200 \mathrm{mg} / \mathrm{kg}$ (i.p.) & $0.17 \pm 0.03^{* *}$ & 53 \\
& $100 \mathrm{mg} / \mathrm{kg}$ (i.p.) & $0.31 \pm 0.05$ & 14 \\
& $200 \mathrm{mg} / \mathrm{kg}$ (i.p.) & $0.29 \pm 0.02$ & 19 \\
EO & $400 \mathrm{mg} / \mathrm{kg}$ (i.p.) & $0.24 \pm 0.01^{*}$ & 33 \\
& $200 \mu \mathrm{l} / \mathrm{kg}$ (p.o.) & $0.30 \pm 0.02$ & 17 \\
Indomethacin & $400 \mu \mathrm{l} / \mathrm{kg}$ (p.o.) & $0.24 \pm 0.04^{*}$ & 33 \\
& $10 \mathrm{mg} / \mathrm{kg}$ (i.p.) & $0.10 \pm 0.01^{* *}$ & 72 \\
\hline
\end{tabular}

${ }^{*} \mathrm{p}<0.05,{ }^{* *} \mathrm{p}<0.001$, compared with control group. HE $=$ Hydroalcoholic extract; $\mathrm{PE}=$ polyphenolic extract; $\mathrm{EO}=$ essential oil.

In the formalin pain model, formalin induced a typical biphasic pain response [17]. High nociceptive scores were recorded during the first $5 \mathrm{~min}$ after subcutaneous formalin administration and this was followed by a reduction in scores for several minutes. A later licking response was also seen $20 \mathrm{~min}$ after formalin injection. Pain in the early phase is predominantly caused by the activation of C-fibers, while in the late phase, a combination of an inflammatory reaction in peripheral tissue and functional changes in the dorsal horn of the spinal cord are involved [24].

In this study, only the hydroalcoholic extract of $S$. hortensis seeds reduced the pain response in both phases of the formalin test. The first phase is associated with acute pain and it has been reported that centrally acting analgesic drugs such as opioids are able to inhibit the pain response in this first phase of the formalin test $[25,26]$. Since the hydroalcoholic extract of $S$. hortensis seeds could suppress this phase of the formalin test, it seems likely that at least a part of its analgesic activity is mediated centrally. The later (second) phase is inflammatory in origin $[25,26]$ and both extracts and the essential oil demonstrated considerable activity in this phase, suggesting the presence of material with anti-inflammatory activity in the seeds of the plant. Results of the carrageenan-induced paw edema test, which is a standard animal model for assessing anti-inflammatory activity, also confirmed the presence of anti-inflammatory activity in S. hortensis seeds.

The results of the present study indicating analgesic and anti-inflammatory effects of $S$. hortensis polyphenolic extract are consistent with our previous studies which demonstrated these effects for flavonoids and polyphenolic compounds of other plants $[4,6,27,28]$.

It has previously been reported that flavonoids and polyphenolic compounds show several pharmacological effects, including antioxidant activity [29], inhibition of histamine release from mast cells and inhibition of arachidonic acid metabolism [30]. On the other hand, car- 
rageenan induces a biphasic edema response. In the first phase $(0-2.5 \mathrm{~h})$, release of mediators, such as histamine, serotonin and kinins, is associated with increased vascular permeability and in the second phase production of prostaglandins and oxygen-derived free radicals is dominant $[5,31]$. However, further investigations are required to find out which of the above mechanisms is involved in the anti-inflammatory effects of the polyphenolic extract observed in this work.

Taking into account the above results, it can be concluded that $S$. hortensis has significant anti-inflammatory and analgesic activities, and this study provides pharma- cological evidence for its traditional use in painful and inflammatory conditions. However, further studies are needed to determine the possible mechanism of action of these fractions, and their potential for clinical use needs to be demonstrated in clinical trials.

\section{Acknowledgements}

This work was supported by the Research Council of Isfahan University of Medical Sciences, Isfahan, Iran (project No. 387308).

\section{References}

1 Zakaria ZA, Mohamad AS, Chear CT, Wong YY, Israf DA, Sulaiman MR: Anti-inflammtory and antinociceptive activities of Zingiber zerumbet methanol extract in experimental model systems. Med Princ Pract 2010;19:287-294.

$\checkmark 2$ Hajhashemi V, Ghannadi A, Pezeshkian SK: Antinociceptive and anti-inflammatory effects of Satureja hortensis L. extracts and essential oil. J Ethnopharmacol 2002;82:83-87.

$\checkmark 3$ Khalid S, Shaik Mossadeq WM, Israf DA, Hashim P, Rejab S, Shaberi AM, Mohamad AS, Zakaria ZA, Sulaiman MR: In vivo analgesic effect of Tamarindus indica L. fruits. Med Princ Pract 2010;19:255-259.

4 Hajhashemi V, Sajjadi SE, Heshmati M: Anti-inflammatory and analgesic properties of Heracleum persicum essential oil and hydroalcoholic extract in animal models. J Ethnopharmacol 2009;124:475-480.

$\checkmark 5$ Panthong A, Kanjanapothi D, Taesotikul T, Phankummoon A, Panthong K, Reutrakul $\mathrm{V}$ : Anti-inflammatory activity of methanolic extracts from Ventilago harmandiana Pierre. J Ethnopharmacol 2004;91:237-242.

6 Hajhashemi V, Sajjadi SE, Zomorodkia M: Antinociceptive and anti-inflammatory activities of Bunium persicum essential oil, hydroalcoholic and polyphenolic extracts in animal models. Pharm Biol 2011;49:146-151.

7 Gulluce M, Sokmen M, Daferera D, Agar G, Ozkan H, Kartal N, Polissiou M, Sokmen A, Sahin F: In vitro antibacterial, antifungal, and antioxidant activities of the essential oil and methanol extracts of herbal parts and callus cultures of Satureja hortensis L. J Agric Food Chem 2003;51:3958-3965.

8 Hajhashemi V, Sadraei H, Ghannadi AR, Mohseni M: Antispasmodic and anti-diarrhoeal effect of Satureja hortensis L. essential oil. J Ethnopharmacol 2000;71:187-192.

9 Leung AY, Foster S: Encyclopedia of Common Natural Ingredients Used in Food, Drugs and Cosmetics, ed 2. New York, Wiley, 1996.
10 Zargari A: Medicinal Plants. Tehran, Tehran University Publications, 1990.

11 Dorman HJ, Bachmayer O, Kosar M, Hiltunen R: Antioxidant properties of aqueous extracts from selected lamiaceae species grown in Turkey. J Agric Food Chem 2004; 52:762-770.

12 Amin G: Popular Medicinal Plants of Iran Tehran, Tehran University of Medical Sciences, 1993.

13 Sajjadi SE, Movahedian-Atar AM, Yektaian A: Antihyperlipidemic effect of hydroalcoholic extract and polyphenolic fraction from Dracocephalum kotschyi Boiss. Pharm Acta Helv 1998;73:167-170.

14 Adams RP: Identification of Essential Oil Components by Gas Chromatography/Mass Spectroscopy. Carol Stream, Allured Publishing Corporation, 1995.

15 Swigar AA, Silverstein RM: Monoterpenes. Infrared, Mass, ${ }^{1} \mathrm{H}-\mathrm{NMR},{ }^{13} \mathrm{C}-\mathrm{NMR} 14$ Spectra and Kovats Indices. St Louis, Aldrich Chemical Company, 1981.

16 Koster R, Anderson M, De Beer EJ: Acetic acid for analgesic screening. Fed Proc 1959; 18:412-417.

17 Hunskaar S, Hole K: The formalin test in mice: dissociation between inflammatory and non-inflammatory pain. Pain 1987;30: 103-114

18 Winter CA, Risley EA, Nuss GW: Carrageenin-induced edema in hind paw of the rat as an assay for anti-iflammatory drugs. Proc Soc Exp Biol Med 1962;111:544-547.

19 Ghannadi A: Composition of essential oil of $S$. hortensis L. seeds from Iran. J Essent Oil Res 2002;14:35-36.

20 Daferera DJ, Ziogas BN, Polissiou MG: GCMS analysis of essential oils from some Greek aromatic plants and their fungitoxicity on Penicillium digitatum. J Agric Food Chem 2000;48:2576-2581.
21 Le BD, Gozariu M, Cadden SW: Animal models of nociception. Pharmacol Rev 2001; 53:597-652.

22 Vogel HG, Vogel WH: Drug Discovery and Evaluation. Berlin, Springer, 1997.

$\checkmark 23$ Collier HO, Dinneen LC, Johnson CA, Schneider C: The abdominal constriction response and its suppression by analgesic drugs in the mouse. Br J Pharmacol Chemother 1968;32:295-310.

24 Tjolsen A, Berge OG, Hunskaar S, Rosland $\mathrm{JH}$, Hole K: The formalin test: an evaluation of the method. Pain 1992;51:5-17.

25 Chen YF, Tsai HY, Wu TS: Anti-inflammatory and analgesic activities from roots of Angelica pubescens. Planta Med 1995;61:2-8.

26 Elisabetsky E, Amador TA, Albuquerque RR, Nunes DS, Carvalho AC: Analgesic activity of Psychotria colorata (Willd. ex R \& S) Muell. Arg. alkaloids. J Ethnopharmacol 1995;48:77-83.

27 Ghannadi A, Hajhashemi V, Jafarabadi H: An investigation of the analgesic and antiinflammatory effects of Nigella sativa seed polyphenols. J Med Food 2005;8:488-493.

28 Hajhashemi V, Ghannadi A, Sharif B: Antiinflammatory and analgesic properties of the leaf extracts and essential oil of Lavandula angustifolia Mill. J Ethnopharmacol 2003;89:67-71.

29 Bors W, Saran M: Radical scavenging by flavonoid antioxidants. Free Radic Res Commun 1987;2:289-294

>30 Amresh G, Reddy GD, Rao C, Singh PN: Evaluation of anti-inflammatory activity of Cissampelos pareira root in rats. J Ethnopharmacol 2007;110:526-531.

-31 Antonio MA, Souza Brito AR: Oral anti-inflammatory and anti-ulcerogenic activities of a hydroalcoholic extract and partitioned fractions of Turnera ulmifolia (Turneraceae). J Ethnopharmacol 1998;61:215-228. 